\title{
Development Model of Digital-Based Dental Health Recording and Reporting Service System in Public Healt Center
}

\author{
Rizke Amalia Fauziah, Masrifan Djamil, Supriyana \\ Poltekkes Kemenkes Semarang, Indonesia \\ Poltekkes Kemenkes Semarang, Indonesia \\ Poltekkes Kemenkes Semarang, Indonesia \\ Email: rizkeamalia74@gmail.com, rifan.mmd@gmail.com, hastama99@yahoo.com
}

\begin{tabular}{|c|c|}
\hline ARTICLE INFO & ABSTRACT \\
\hline $\begin{array}{l}\text { Received } \\
23 \text { Juny } 2021 \\
\text { Revision } \\
1 \text { July } 2021 \\
\text { Approved } \\
10 \text { July } 2021 \\
\text { Keywords: } \\
\text { Digital-based } \\
\text { system development } \\
\text { service } \\
\text { recording } \\
\text { reporting model }\end{array}$ & $\begin{array}{l}\text { The Puskesmas Information Reporting System (SIP) has been in since } \\
1981 \text {. In its implementation, SIP was still limited to data which was } \\
\text { the result of interactions between the community and health facilities. } \\
\text { Methods used Research and Development (R\&D). Collecting data by } \\
\text { interview, observation, and documentation. The sample contained } \\
\text { sample I amounted were } 6 \text { people, sample II were } 25 \text { people, and } \\
\text { sample III were } 16 \text { people. Sampling technique with non probability } \\
\text { sampling. Data analyswas used univariate and bivariate analyswas. } \\
\text { Result that designed and built after being tested by experts, it was } \\
\text { feasible to apply the Digital-Based Dental Health Recording and } \\
\text { Reporting Service System Development Model. The Development } \\
\text { Model of the Digital-Based Dental Health Recording and Reporting } \\
\text { Service System after being tested has been proven to be } \\
\text { relevant/suitable for use in the implementation of the digital-based } \\
\text { dental health recording and reporting service system at the Puskesmas } \\
\text { in Boyolali Regency. The Development Model of the Digital-Based } \\
\text { Dental Health Recording and Reporting Service System has effective } \\
\text { for the substance of the application system and improves the quality } \\
\text { of the measurement before and after the development of a dental } \\
\text { health recording and reporting service system based at the Puskesmas } \\
\text { in Boyolali District with p value =0.001. Conclusion that Development } \\
\text { Model of the Digital-Based Dental Health Recording and Reporting } \\
\text { Service System has effective for the substance of the application } \\
\text { system and improves the quality dental health recording and reporting } \\
\text { service system based at the Puskesmas. }\end{array}$ \\
\hline
\end{tabular}

\section{INTRODUCTION}

The implementation of health services was every effort that was carried out alone or jointly in order to improve and maintain health, prevent dwasease, treat dwasease and restore health of individuals, groups and communities. The main objectives of health services were preventive and promotive (health improvement) services targeting the community.
Minister of Health Republic of Indonesia Number 75 of 2014 states that the Community Health Center (Puskesmas) was a health service facility that organizes public health efforts and first-level individual health efforts (Mujiati \& Yuniar, 2016). Puskesmas organizes the first level of UKM (Public Health Efforts) and organizes UKP Individual) the first level in their working area (Maghfiroh \& Rochmah, 2017). 
Puskesmas management was a series of activities that work systematically to produce effective and efficient Puskesmas outcomes. A series of systematic activities was carried out by the Puskesmas with attention to management functions (Nurmandi, 2018). One of the Puskesmas management activities was the implementation of control, namely a series of activities ranging from organizing, organizing, monitoring the local area/PWS with data from health recording and reporting in the Workshop forum. Mini Puskesmas (Nurmandi, 2018).

Efforts made in the activity or process of documenting dental and oral health services to monitor and analyze the development of dental and oral deases in the district/city use recording and reporting. Recording was an activity or process of documenting an activity in written form, while reporting was a record that provides information about a particular activity and its results which were conveyed to the authorized party or related to that activity (Nilawati, Sugiarsi, \& Darnoto, 2016).

One of the requirements for Puskesmas accreditation was the adminwastration and management of Puskesmas based on the Regulation of the Minister of Health of the Republic of Indonesia Number 75 of 2014 concerning Puskesmas, recording and reporting was part of the Health Information System (SIK) of Puskesmas that must be carried out (Nilawati et al., 2016). When compwered to the 4.0 era, recording and Manual reporting was very ineffective and time efficient at the time of collecting the documentation files and reporting them to the authorized party (Tjandrawinata, 2016).

Puskesmas reporting related to activities and achievements that have been carried out using the Puskesmas Information System (SIP) was an activity and reporting of general data, facilities, personnel and health service efforts in the community in accordance with Government Regulation number 46 of 2014 concerning health information systems, This was implement the provwasions of Article 168 paragraph (3) of Law number 36 of 2009 concerning health (Suryani \& Solikhah, 2013).

The results of the government's efforts on recording and reporting at Puskesmas in the era 4.0, namely there were still weaknesses in the development of the National Health Information System, namely that most regions do not have adequate capabilities in implementing health information systems, data and information by management was not optimal, health data and information by the community was underdeveloped, telematics technology was not yet optimal, funds for the development of the health information system were limited, there was a lack of full-time health information system personnel (Niken, 2019).

SIP has been in effect since 1981. In its implementation, SIP was still limited to data which was the result of interactions between the community and health facilities. The various SIP data available to support Puskesmas management have not been utilized optimally. Resources were limited in Puskesmas in terms of people and supporting facilities. Recording and reporting using SIP was currently not yet fully implemented in the Puskesmas/sub-district area (Departemen Kesehatan RI, 2019).

Government Regulation number 46 of 2014 concerning Health Information Systems (SIK), This was to implement the provwasions of article 168 paragraph (3) of Law number 36 of 2009 concerning health. Evaluation of recording and reporting at Puskesmas using the Health Metricts Network-World Health Organization (HMN-WHO) toolkit. The results obtained were that GWAS was present but inadequate for resources $(47 \%)$, indicators $(61 \%)$, data sources $(51 \%)$, data quality $(55 \%)$, data use and dwassemination (57\%), for data management ( $35 \%)$, so that in general these results indicate that the overall GWAS still needs to be improved (Miah, Gammack, \& Hasan, 2017).

The health information system could be a softwwere that can make it easier for health workers and the Health Office to determine the procedures and policies that were used to systematically manage the information cycle to support the implementation of integrated and comprehensive health management within the framework of health services to the community. For This purpose a health information system needs to be built by organizing various data that have been collected systematically and processing the data into useful information (Ramadhani, Anis, \& Masruro, 2013). 
Recording and reporting were indicators of the success of activities. The output of recording and reporting was valuable and valuable data and information when using the right and correct method. Data and information were the most important elements in a Puskesmas, because it could be seen about the success or development of the Puskesmas (Mangaro \& Setyowati, 2014). Therefore, medical record services at Puskesmas need to be improved with digitalization innovations. Innovative models for the development of a digital-based dental health recording and reporting service system in Puskesmas. This model can make it easier for dental health workers to record, report, process and analyze dental health data carried out in public health units and individual health units (Mangaro \& Setyowati, 2014).

Research of Febrianto, Putra, and Perdanakusuma in the SIMPUS time efficiency aspect, the results obtained were $100 \%$, which means that the overall time obtained in completing the task was quite good (Febrianto, Putra, \& ..., 2019). Based on the time-based efficiency results that have been obtained, the difference in the time to complete the task The fastest and the longest tasks were obtained based on the differences in interactions that occur between the first task and the sixth task where the first task the user was only asked to log in to the SIMPLE application while for the sixth task the user was asked to perform patient data execution which has more activity than the task that was used. the first to just log in to the SIMPLE application.

The results of Wariyanti, Harjanti, and Sugiarsi's research show that filling out This important report must be filled completely because important reports were used to determine the patient's dwasease course and show further diagnoswas (Wariyanti, Harjanti, \& Sugiarsi, 2019). In This report recording the date and time of recording was important because it was related to the regulation that recording Medical records must be completed within $1 \times 24$ hours at the latest (Aryanti, 2014; Rani \& Ernawati, 2014; Wariyanti et al., 2019).

The results of the research conducted by Nazir and Darmawati (Nazir \& Darmawati, 2018) and Andriyani and Perdana(Andriyani \& Perdana, 2014) show that with SIP data reporting information system application, the city health office can easily control and recap SIP data reported by all Puskesmas quickly and on time. Thus the development of health data could be realtime, reports on time, completed on time, effective, efficient and useful for the preparation of health development planning (Azizah, 2018; Budi \& Rokhman, 2014; Gulo \& Simamora, 2018; Maman, 2016).

Other research results show that electronic medical records can have a negative impact on doctor and patient communication, such as dwasruption of confinement due to focusing too much on the screen while filling out medical records, but on the other hand, it can have a positive effect, namely that it can make it easier to carry out integrated services (Alkureishi et al., 2016). In terms of time, in general, it takes a longer time to fill out electronic medical records than manual medical records. Perry's research shows that from a study of 1 nontraumatic chest pain patient before the use of electronic medical records and 76 nontraumatic chest pain patients after using electronic medical records, the time for documenting electronic medical records was longer, namely 9.6 minutes compwered to conventional medical records of about 6.1 minute (Perry et al., 2014).

The results of a preliminary study conducted on field work practice (PKL) students of the Applied Master of Dental and Oral Therapwast Health Study Program in September-October 2018 at the Boyolali District Health Office obtained information on the results of interviews with officers in charge of the District Health Office SIP. Boyolali problems that exwast in several Boyolali Puskesmas were (1) Delays in sending SIP reports; (2) Data on Dental Health was incomplete; (3) the person in charge of recording and reporting system data at the Puskesmas does not send the data to the Health Office; (4) Lack of coordination between reporting system managers and officers at Puskesmas. (5) there was still manual recording and reporting of Puskesmas, which hinders reporting to the Health Office even though there was an SIP, (6) there was a lack of personnel in charge of the Health Office information system. Based on these conditions, it was necessary to develop a data collection method for the 
rwask of dental and oral dwaseases that aims to improve the quality of sustainable dental and oral health services (Dinas Kesehatan Kabupaten Boyolali, 2018). The aim of This study was to produce a model for developing a digital-based dental health recording and reporting service system and to analyze its effectiveness for the quality of the dental health recording and reporting system at the Puskesmas.

\section{METHOD}

The method used was Research and Development (R\&D). Steps were done in this study in depth:

1. The process of gathering information, product/model design, expert validation and revwasion, product/model testing, and product/model results. Collecting information by analyzing needs, identifying and analyzing problems experienced in the implementation of recording and reporting of dental and oral health. The data collected from information collection was used to create a model for the development of digitalbased dental health recording and reporting service system. Expert validation test was used to test the feasibility of product before it was used for the public. Internal testing was planned to be carried out by 3 experts, namely health promotion experts, IT experts, and Puskesmas management experts. Data collection techniques using structured (structured interviews), observation, and documentation. Tests were carried out to produce product/model suitable for use.

2. Product trial was carried out by applying product designs in real conditions. The test design used a quasy experimental Non-Randomized Control Group Pretest And Posttest Design (Non Equivalent Control Group). This design was more applicable to examining the causal relationship between two groups in situations where random selection was not possible. This design was used to analyze the effect of the development model for dental and oral health recording and reporting systems in the health information system in the form of the use of digital-based information systems on the value of the substance in the system and the value of the quality of dental health recording and reporting system information. The result of the product/model in the form of model for the development of digital-based dental health recording and reporting service system at Puskesmas was the output of the development of dental health recording and reporting service system at the Puskesmas.

Sample I of research subjects for the information collection stage was carried out by non-probability sampling totaling 6 people from the Health Office including the Head of Public Health Center Management, the Head of Health and IT, Head of Public Health Centers, dental health personnel (dentwasts and dental therapwasts). Sample II research subjects for expert validation and revwasion with non-probability sampling 1 Dental and Oral Therapwast (TGM) in each Puskesmas with total were 25 respondents. Sample III using total sample, namely all dental therapwasts from all Puskesmas in Boyolali Regency were 16 respondents.

Data processing used editing, coding, and data tabulation. Validity test used product moment correlation and reliability test uses Cronbach's alpha. Normality of data using Shapiro-Wilk. Univariate analys was used frequency dwastribution. Bivariate analysys if data was normally distributed, bivariate analysis uses Paired t-test, if data was not normally distributed, data analyswas used Wilcoxon. Multivariate analysis used linear regression analysis.

\section{RESULTS AND DISCUSSION}

\section{A. Information Gathering}

The results of the collection of information were carried out by interviewing the Health Office covering the field of Health Services, the field of Health Promotion and IT, Head of Public Health Centers, dental health personnel (Dentwasts and Oral and Dental Therapwasts).

\section{B. Information Systems Framework}

The model framework for developing a digital-based dental health recording and reporting service system in Puskesmas with a Digital-Based Dental Health Recording and Reporting Service System Development Model conswasts of input, process, and output and determination of 
the exwasting system (SIMPUS) and the system to be built (Development Model Digital-Based Dental Health Recording and Reporting Service System in Puskesmas).

\section{System Process Design}

Using use case diagrams and activity diagrams. The use case diagram was a diagram for modeling aspects of system behavior. This diagram shows a set of use cases, actors, and their relationships. Use cases were functionality of the system that actors initialize. The actors in This study were oral and dental therapwasts. Activity diagrams were actually a special form of state machines that aim to model computations and work flows that occur in systems/softwwere being developed.

D. Product Design/Model
Data resulting from information collection was used to design a product or model. The results of information collection revealed that there was no development model for digital-based dental health recording and reporting in Puskesmas so that the ongoing system was unable to answer the challenges in the global millennial era for dental health at Puskesmas, so the researchers created a model for developing a service-based dental health recording and reporting service system. digital services in Puskesmas that were tailored to the needs of a suitable method for recording and reporting dental health at the Puskesmas. The following describes the stages of the development model for a digital-based dental health recording and reporting service system at the Puskesmas.

\section{E. Expert Validation Test}

Table 1

Expert Validation Test

\begin{tabular}{ccccc}
\hline Number & Experts & Score & $\begin{array}{c}\text { Average } \\
\text { Score }\end{array}$ & $\begin{array}{c}\text { P- } \\
\text { Value }\end{array}$ \\
\hline 1 & $\begin{array}{c}\text { Dental and Oral } \\
\text { Therapwasts (TGM) }\end{array}$ & 94,7 & & \\
\hline 2 & $\begin{array}{c}\text { Information } \\
\text { Technology Experts } \\
\text { (IT) }\end{array}$ & 97,4 & 96,5 & 0,001 \\
\hline 3 & Management Experts & 97,4 & & \\
\hline Intraclass Correlation Coefficients & & & \\
\hline
\end{tabular}

Based on the results of the assessment from the expert validator, it was known that the average feasibility score was 96.5 in the very feasible category (without revwasion). The results of expert validity show that the $p$-value of 0.001 means that the Development of Digital-Based Dental There were 3 expert validations, namely Dental and Oral Therapwasts (TGM), Health Promotion), Information Technology (IT) Experts, and Management Experts.

Health Recording and Reporting Service System was relevant and feasible as a dental health recording and reporting system in the Puskesmas.

\section{F. Product/Model Trials}

\section{Univariate Analysis}

Table 2

Dwastribution Frequency Based on Characterwastics of Health Workers in Puskesmas

\begin{tabular}{ccc}
\hline Variables & Frequention & $\begin{array}{c}\text { Percentage } \\
(\%)\end{array}$ \\
\hline Age & 1 & 4.0 \\
\hline Early Adulthood (26-35 years) & 16 & 64.0 \\
\hline Late Adulthood (36-45 years) & & \\
\hline
\end{tabular}




\begin{tabular}{ccc}
\hline Early Elderly $(46-55$ years) & 8 & 32.0 \\
\hline Gender & 9 & 36.0 \\
\hline Male & 16 & 64.0 \\
\hline Female & & \\
\hline Length of Working & 8 & 32.0 \\
\hline $10-15$ years & 12 & 48.0 \\
\hline $16-20$ years & 4 & 16.0 \\
\hline $21-25$ years & 1 & 4.0 \\
\hline $26-30$ years & & \\
\hline Education & 18 & 72.0 \\
\hline Diploma & 7 & 28.0 \\
\hline Bachelor &
\end{tabular}

Table 2 shows that 25 respondents, dental and oral therapwasts at Puskesmas in the working area of District Health Office.

Boyolali, some was aged $36-45$ years (late adults), were 16 people $(64.0 \%)$. In terms of gender, most of the respondents were female, were 16 people (64.0\%).
Based on the length of work, most of the respondents have worked for 16-20 years, were 12 people (48.0\%). Then based on the characterwastics of their education, most of the respondents had diploma education, were 18 people ( $72.0 \%)$.

Table 3

Average Value of Application System Substance Aspects and Information Quality Before and After the Development Model of Digital-Based Dental Health Recording and Reporting Services

\begin{tabular}{lllll}
\hline \multirow{2}{*}{ Composite Variables } & \multicolumn{4}{c}{ Statistics } \\
\cline { 2 - 5 } & Mean & SD & Min & Max \\
\hline General Substantion Aplication & & & & \\
\hline General Substantion_Pre & 6 & 1.528 & 4 & 9 \\
\hline General Substantion_Post & 9.72 & 1.242 & 8 & 12 \\
\hline Ease of Using_Pre & 9.92 & 2.783 & 7 & 15 \\
\hline Ease of Using_Post & 16.24 & 1.234 & 13 & 18 \\
\hline Ease of Learning_Pre & 3.92 & 1.256 & 2 & 6 \\
\hline Ease of Learning_Post & 6.6 & 0.866 & 5 & 8 \\
\hline Response Time_Pre & 11.88 & 3.283 & 8 & 18 \\
\hline Response Time_Post & 19.32 & 1.676 & 17 & 22 \\
\hline Ease of Menu and Availability_Pre & 3.88 & 1.130 & 3 & 6 \\
\hline Ease of Menu and Availability_Post & 6.28 & 0.792 & 5 & 8 \\
\hline System Reability_Pre & 3.76 & 1.052 & 3 & 6 \\
\hline System Reability_Post & 6.44 & 0.821 & 5 & 8 \\
\hline Completeness of Features_Pre & 31.88 & 8.323 & 23 & 48 \\
\hline Completeness of Features_Post & 55.12 & 2.472 & 50 & 62 \\
\hline Information Quality & & & & \\
\hline Completeness of Information_Pre & 19.64 & 2.644 & 15 & 14 \\
\hline Completeness of Information_Post & 23.44 & 0.870 & 21 & 24 \\
\hline Easiness_Pre & 12.88 & 2.147 & 8 & 16 \\
\hline Easiness_Post & 15.48 & 0.714 & 14 & 16 \\
\hline Accuration_Pre & 16.36 & 2.307 & 13 & 20 \\
\hline Accuration_Post & 19.64 & 0.700 & 18 & 20 \\
\hline Relevantion_Pre & 9.8 & 1.756 & 6 & 12 \\
\hline Relevantion_Post & 11.64 & 0.757 & 9 & 12 \\
\hline Punctuality_Pre & 3.24 & 0.597 & 2 & 4 \\
\hline & & & & \\
\hline
\end{tabular}




\begin{tabular}{lllll}
\hline Punctuality_Post & 3.92 & 0.277 & 3 & 4 \\
\hline Information Conswastency_Pre & 3.44 & 0.583 & 2 & 4 \\
\hline Information Conswastency_Post & 3.84 & 0.374 & 3 & 4 \\
\hline Report Conswastency_Pre & 3.48 & 0.510 & 3 & 4 \\
\hline Report Conswastency_Post & 3.88 & 0.332 & 3 & 4 \\
\hline Total_Pre & 140.08 & 25.59 & 110 & 187 \\
\hline Total_Post & 201.56 & 5.82 & 192 & 218 \\
\hline
\end{tabular}

Table 3 shows the average value of the general substance aspects of all applications that have increased in value before and after the provwasion of information systems. The highest increase in the completeness of the previous features was 31.88 , an increase of 55.12 .
The average value of all aspects of information quality has increased in value before and after the provwasion of information systems. The highest increase in the completeness of the information aspect, which was 19.64, increased to 23.44 .

Table 4

Normality Test

\begin{tabular}{ll}
\hline \multicolumn{1}{c}{ Variables } & p-value \\
\hline General Substantion Aplication & \\
\hline General Substantion_Pre & 0.006 \\
\hline General Substantion_Post & 0.001 \\
\hline Ease of Using_Pre & 0.001 \\
\hline Ease of Using_Post & 0.001 \\
\hline Ease of Learning_Pre & 0.001 \\
\hline Ease of Learning_Post & 0.001 \\
\hline Response Time_Pre & 0.001 \\
\hline Response Time_Post & 0.004 \\
\hline Ease of Menu and Availability_Pre & 0.001 \\
\hline Ease of Menu and Availability_Post & 0.003 \\
\hline System Reability_Pre & 0.001 \\
\hline System Reability_Post & 0.005 \\
\hline Completeness of Features_Pre & 0.001 \\
\hline Completeness of Features_Post & 0.073 \\
\hline Information Quality & \\
\hline Completeness of Information_Pre & 0.091 \\
\hline Completeness of Information_Post & 0.001 \\
\hline Easiness_Pre & 0.127 \\
\hline Easiness_Post & 0.001 \\
\hline Accuration_Pre & 0.064 \\
\hline Accuration_Post & 0.001 \\
\hline Relevantion_Pre & 0.016 \\
\hline Relevantion_Post & 0.001 \\
\hline Punctuality_Pre & 0.001 \\
\hline Punctuality_Post & 0.001 \\
\hline Information Conswastency_Pre & 0.001 \\
\hline Information Conswastency_Post & 0.001 \\
\hline Report Conswastency_Pre & 0.001 \\
\hline Report Conswastency_Post & 0.001 \\
\hline Total_Pre & $\mathbf{0 . 0 0 2}$ \\
\hline Total_Post & $\mathbf{0 . 3 7 4}$ \\
\hline Shapiro-Wilk & \\
\hline
\end{tabular}

Shapiro-Wilk 
Table 4 shows the $p$-value for all variables, both pretest and posttest, all $<a$ $(0.05)$, so it shows that the data from these after the provwasion of information systems. The highest increase in the completeness of the information aspect, which was 19.64, increased to 23.44.

variables were not normally dwastributed. Except, for the variables of completeness of posttest features, completeness of pretest, ease of pretest, accuracy of pretest, and total posttest obtained p-value $>$ a $(0.05)$, so that it were normally dwastributed. Thus, because the data were not normally dwastributed, the test used to analyze the effectiveness used the Wilcoxon test.

\section{Bivariate Analysis}

Table 5

Analyswas of the Development Model for Digital-Based Dental Health Recording and Reporting Services Before and After Providing Information Systems

\begin{tabular}{|c|c|c|c|c|c|c|}
\hline Variabel & Treatments & $\mathbf{N}$ & Mean & SD & $\mathbf{Z}$ & p-value \\
\hline \multicolumn{7}{|l|}{$\begin{array}{l}\text { General Substantion } \\
\text { Aplication }\end{array}$} \\
\hline \multirow[t]{2}{*}{ General Substantion } & Before & 25 & 6.00 & 1.53 & -4.038 & 0.001 \\
\hline & After & 25 & 9.72 & 1.24 & & \\
\hline \multirow[t]{2}{*}{ Ease of Using } & Before & 25 & 9.92 & 2.78 & -4.119 & 0.001 \\
\hline & After & 25 & 16.24 & 1.23 & & \\
\hline \multirow[t]{2}{*}{ Ease of Learning } & Before & 25 & 3.92 & 1.26 & -4.063 & 0.001 \\
\hline & After & 25 & 6.60 & 0.87 & & \\
\hline \multirow[t]{2}{*}{ Response Time } & Before & 25 & 11.88 & 3.28 & -4.206 & 0.001 \\
\hline & After & 25 & 19.32 & 1.68 & & \\
\hline Ease of Menu and & Before & 25 & 3.88 & 1.13 & -4.100 & 0.001 \\
\hline Availability & After & 25 & 6.28 & 0.79 & & \\
\hline \multirow[t]{2}{*}{ System Reability } & Before & 25 & 3.76 & 1.05 & -4.334 & 0.001 \\
\hline & After & 25 & 6.44 & 0.82 & & \\
\hline \multirow[t]{2}{*}{$\begin{array}{c}\text { Completeness of } \\
\text { Features }\end{array}$} & Before & 25 & 31.88 & 8.32 & -4.376 & 0.001 \\
\hline & After & 25 & 55.12 & 2.47 & & \\
\hline \multicolumn{7}{|l|}{ Information Quality } \\
\hline \multirow[t]{2}{*}{$\begin{array}{c}\text { Completeness of } \\
\text { Information }\end{array}$} & Before & 25 & 19.64 & 2.64 & -4.301 & 0.001 \\
\hline & After & 25 & 23.44 & 0.87 & & \\
\hline \multirow[t]{2}{*}{ Easiness } & Before & 25 & 12.88 & 2.15 & -4.224 & 0.001 \\
\hline & After & 25 & 15.48 & 0.71 & & \\
\hline \multirow[t]{2}{*}{ Accuration } & Before & 25 & 16.36 & 2.31 & -4.159 & 0.001 \\
\hline & After & 25 & 19.64 & 0.70 & & \\
\hline \multirow[t]{2}{*}{ Relevantion } & Before & 25 & 9.8 & 1.76 & -4.072 & 0.001 \\
\hline & After & 25 & 11.64 & 0.76 & & \\
\hline \multirow[t]{2}{*}{ Punctuality } & Before & 25 & 3.24 & 0.60 & -4.123 & 0.001 \\
\hline & After & 25 & 3.92 & 0.28 & & \\
\hline \multirow[t]{2}{*}{$\begin{array}{l}\text { Information } \\
\text { Conswastency }\end{array}$} & Before & 25 & 3.44 & 0.58 & -3.162 & 0.002 \\
\hline & After & 25 & 3.84 & 0.37 & & \\
\hline \multirow[t]{2}{*}{ Report Conswastency } & Before & 25 & 3.48 & 0.51 & -3.162 & 0.002 \\
\hline & After & 25 & 3.88 & 0.33 & & \\
\hline \multicolumn{7}{|c|}{ Total Scores of Effectiveness } \\
\hline Total Scores of & Before & 25 & 140.08 & 25.59 & -4.373 & 0.001 \\
\hline Questionnaire & After & 25 & 201.56 & 5.82 & & \\
\hline Wilcoxon test & & & & & & \\
\hline
\end{tabular}


Application system substance, information quality, and total effectiveness score, it showed that there were significant differences in the value of general substance aspects, information quality, and the total score of the recording and reporting system application system dental health before and after used Digital-Based Dental Health Recording and Reporting Service System Development Model.

\section{Table 6}

Effect of Confounding (Education) Variables on Digital-Based Dental Health Recording and Reporting System Interventions

\begin{tabular}{ccccc}
\hline \multirow{2}{*}{ Educations } & \multicolumn{3}{c}{ Score } & \multirow{2}{*}{ Total } \\
\cline { 2 - 4 } & $\mathbf{1 9 2 - 2 0 5}$ & $\mathbf{2 0 6 - 2 1 9}$ & \multirow{2}{*}{ p-value } \\
\hline Diploma & 14 & 4 & 18 & \multirow{2}{*}{1,000} \\
\hline Bachelor & 6 & 1 & 7 & \\
\hline Total & 20 & 5 & 25 & \\
\hline
\end{tabular}

\section{Chi-Squwere}

Based on table 6, it could be seen that the p-value was 1,000 , so the educational confounding variable has no effect on the digital-based dental health recording and reporting system intervention.

\section{a. Application System Substance}

The results of the research on the general substance aspect with a $\mathrm{p}$-value of 0.001 indicate that the use of the information system from the general substance aspect was complete and sufficient for the data needed in recording and reporting dental health. These results were in accordance with Azizah's research showing that the general substance factors of filling out medical records were seen from the perspective of man, material, machine, and method (Azizah, 2018).

The results of the research on the aspect of ease of use with a p-value of 0.001 indicate that the use of information systems from the convenience aspect has helped make it easier for officers to record and report dental health. The results of This study were in accordance with the 2016 Institute of Medicine (IOM) report series that ineffective service coordination was due to poor communication between health workers in providing and deciding clinical services provided. IOM recommends electronic medical records as a supporting medium for improving the quality of patient cwere through easy accessibility of information (Maliang, Imran, \& Alim, 2019). Usability was a quality measure that could be used to provide a value for the convenience of an interface that was used by users by using certain criteria. The SIMPLE application was still classified as a new application for usability measurement using three components of analyswas aspects according to WASO 9241-11, namely effectiveness, efficiency and satwasfaction (Sibuea, 2016). The results of This study were in accordance with the standard study of the Puskesmas Information System (SIP) electronic to make it easier for officers to take notes and in making reports and in providing reports to districts/cities, provinces and up to the center. Adminwastrative information system applications make it easy to produce reports that were relevant, accurate, and timely (Andriyani \& Perdana, 2014; Budi \& Rokhman, 2014; Gulo \& Simamora, 2018).

The results of the study on the ease of learning aspect with a p-value of 0.001 , showed that the use of information systems from the easy-to-learn aspect helped make it easier for officers to learn about dental health recording and reporting programs. The results of This study were in accordance with the research that the Puskesmas Management Information System (SIMPUS) was an easy-to-learn system, almost all Puskesmas employees master the operation of SIMPUS. This system was easy to operate, input data only by following the exwasting menu pattern in SIMPUS, then the system will automatically classify data, store and process data into information, so that each section can access the data or information 
needed (Handayani \& Izzatusholekha, 2014). SIMPUS was also a user-friendly program. SIMPUS uses the Windows Operating System, dwasplays graphically and was easy to use. Easy storage system. To dwasplay the data output process could be accessed by using the mouse.

The results of the research on the response time aspect with a $p$-value of 0.001 indicate that the use of information systems from the aspect of response time helps officers in running and operating dental health recording and reporting programs. In one day the number of vwasitors to the Puskesmas can reach 100 people, so in one year there will be thousands of medical record data. The large number of medical records that must be managed by the Puskesmas creates problems because it requires a large amount of manpower, time and space. The method of recording medical records on paper was one of the main factors in the size of the needs that must be met. Searching for a single sheet of medical records from all over the paper shelf can take a lot of time. Paper media medical records by employees cause many weaknesses, including that they take a long time, were less accurate, and can produce incomplete information (Utami, 2015).

The development of an information system as a means of recording digital medical records can accelerate the processing of medical records and reduce the space allocated for storing thousands of medical record papers (Yuliartanto, Rochim, \& Windasari, 2014). The development of an adminwastrative information system can speed up the process of processing patient adminwastrative data up to the process of making reports, so that the time required shorter, efficiency in cost management and the resulting information was more accurate (Utami, 2015). The quality of health services provided to the public could be improved properly if it was supported by a good reporting system that was complete information and the data must be received on time (Nazir \& Darmawati, 2018).

The results of This study were in accordance with the research of Febrianto,
Putra, and Perdanakusuma in the SIMPUS time efficiency aspect, the results obtained were $100 \%$, which means that the overall time obtained in completing the task was quite good (Febrianto, Putra, \& ..., 2019). Based on the time-based efficiency results that have been obtained, the difference in the time to complete the task The fastest and the longest tasks were obtained based on the differences in interactions that occur between the first task and the sixth task where the first task the user was only asked to log in to the SIMPLE application while for the sixth task the user was asked to perform patient data execution which has more activity than the task that was used. the first to just log in to the SIMPLE application.

The results of Wariyanti, Harjanti, and Sugiarsi's research show that filling out This important report must be filled completely because important reports were used to determine the patient's dwasease course and show further diagnoswas (Wariyanti, Harjanti, \& Sugiarsi, 2019). In This report recording the date and time of recording was important because it was related to the regulation that recording Medical records must be completed within $1 \times 24$ hours at the latest (Aryanti, 2014; Rani \& Ernawati, 2014; Wariyanti et al., 2019).

The results of the research conducted by Nazir and Darmawati (Nazir \& Darmawati, 2018) and Andriyani and Perdana(Andriyani \& Perdana, 2014) show that with This SIP data reporting information system application, the city health office can easily control and recap SIP data reported by all Puskesmas quickly and on time. Thus the development of health data could be realtime, reports on time, completed on time, effective, efficient and useful for the preparation of health development planning (Azizah, 2018; Budi \& Rokhman, 2014; Gulo \& Simamora, 2018; Maman, 2016).

The results of the research on the usability and menu availability aspects with a p-value of 0.001 , indicate that the use of information systems from the aspects of usability and time availability helps officers in running and operating dental health recording and reporting programs. The main problems and 
obstacles in the implementation of recording and reporting medical records were not yet were of the benefits and uses of medical records, both in health service facilities and in individual practices, so that the medical records made were incomplete, unclear and not on time. Recording and reporting of medical records was very decwasive in analyzing cases as the main means of accurate evidence (Mangentang, 2015). Availability of data sources was the main requirement for the success of measuring quality. The incompleteness of filling out medical records greatly affects the quality of medical records, because the quality of medical records was a reflection of whether or not the quality of service at the Puskesmas was good.

The results of This study were in accordance with Honni's research (Honni, 2013) that the use and availability of an online health application system menu that could be applied at Puskesmas so that it can improve health services to the community with a relatively low investment. In the exwasting health system in general, patients and health workers were dealing with data through applications that were available for each of these sections separately. The development of a medical record information system was aimed at supporting the availability of information data for management and service implementers as well as the development of a health information network (Utami, 2015).

The results of the research on the reliability aspect of the system with a $p$ value of 0.001 , indicate that the use of information systems from the aspect of ease of system reliability could be relied on by officers in using dental health recording and reporting programs. As one of the public service institutions, Puskesmas requires the exwastence of an information system that was accurate and reliable, and adequate to improve its services to patients and other related environments (Utami, 2015). Data management at Puskesmas was one of the important components in realizing an information system. So far, all data processing that occurs at the Puskesmas, such as patient data processing, medical record data processing, transaction data processing, and reporting per period, were still carried out conventionally or were still using paper media by employees, causing many weaknesses, including requiring a lot of time. long, inaccurate, and so that it can produce incomplete information.

The results of This study were in accordance with Roswiani's research that according to an evaluation conducted by the DI Yogyakarta Health Office in 2012, all Puskesmas in DI Yogyakarta, namely 121 Puskesmas have used Simpus independently, with development no longer relying on facilitation from the DI Yogyakarta Health Office, but developed independently. district/city (Roswiani, 2016). The development of Simpus in each Puskesmas was carried out entirely by the district/city, both in terms of budget and choice of technology used. Although the pilot project uses the IHIS application, districts/cities were given the widest opportunity to choose the most appropriate information technology implemented in each Puskesmas.

The results of the research on the completeness of the features with a pvalue of 0.001 indicate that the use of information systems from the aspect of completeness of features was very helpful for officers in using dental health recording and reporting programs. The process of identifying needs, initial designing to improving the system design, runs quite smoothly, because users were quite interactive and open, making it easy for employees to operate. The completeness of This system design means that the exwasting features cannot be added more fully and could be operated properly. The exwasting system can still be updated and integrated between other sub-systems, and the system was still based on multiple users. In This system the output produced was in the form of printed reports that were in accordance with the wwashes of the user (Hakam \& Alis Setiyadi, 2014).

Usability component that measures the accuracy and completeness that users get in achieving goals. The usability component that measures the resources needed to produce and the level of 
accuracy of completeness in achieving the goal.86 The results of This study were in accordance with Aryanti's research that on average the completeness of filling in electronic medical records was complete. human, facilities and infrastructure, materials, methods, and costs. The results of Nur and Irwandy's research show that the need for users to develop systems that were capable of supporting data processing and can provide clear information and could be directly accessed by managerials (Saud, Kapalawi, \& Noor, 2013).

\section{b. Information Quality}

The results of the research on the completeness aspect of information with a p-value of 0.001 indicate that the use of information systems from the aspect of completeness of information for officers has been able to asswast officers with a system for recording and reporting dental health. The model for the development of a digital- based dental health recording and reporting service system has complete information. This technology offers more information, for example in terms of virtualization, than previous manual methods and can easily be profit-oriented and rapidly changing (Honni, 2013). This digital system recording and reporting model also combines the advantages of open-source patterned applications with system design. flexibility for implementation and development needs, as well as supporting devices to improve the quality of Puskesmas services. The results of This study were in accordance with Prasetyo's research that the DigitalBased Dental Health Recording and Reporting Service System was a flexible method because it can identify various kinds of modeling techniques used in design, because This method could be adjusted to changes and needs during the design (Prasetyo, 2015).

The results of the research on the convenience aspect with a p-value of 0.001 indicate that the use of information systems from the convenience aspect has been able to help officers with a system for recording and reporting dental health programs. For This reason, it was necessary to create a Digital-Based Dental Health Recording and Reporting Service
System Development Model that processes data effectively and efficiently, with the aim of facilitating employee performance in recording patient data in terms of data processing and minimizing errors in conventional data input and optimizing security (Utami, 2015). Admin login aims for data security (Gulo \& Simamora, 2018). Digital-based systems could be added to the login function with a password form for information system security (Andriyani \& Perdana, 2014). The computer facilities needed in implementing Integrated Sikda include server computers, client computers and supporting networks. In managing the server computer, it was expected that the aspects of convenience were still concerned (Maman, 2016).

The results of This study were in accordance with Prasetyo's research that the system for recording and reporting medical records of Majalengka Hospital has used softwwere technology for easy operation of the operating system (OS), security softwwere (firewall), softwwere for e-mail processing (electronic mail), DBMS softwwere (Database). Menegement Systems), programming language softwwere and other office processing softwwere (Maman, 2016). The results of Hakam and Setiyadi's research show that digital-based system development uses the Prototyping Method, which identifies needs such as recording and processing data, information needs, and data security needs (Hakam \& Alis Setiyadi, 2014). Results Pasaribu and Sihombing research that This information system can provide security with login system (Pasaribu, 2016).

The results of the research on the accuracy aspect with a p-value of 0.001 indicate that the use of the information system from the accuracy aspect shows that the dental health recording and reporting system program was able to process and present data accurately. The results of This study were in accordance with the research, the main use of accurate medical records was as evidence of the patient's dwasease course and the treatment that has been given, a means of communication among health workers who provide cwere to patients, a source of 
information for research and education, as well as a source in collecting statwastical data. health. The usefulness of medical records could be viewed from several aspects, namely aspects of accuracy, adminwastrative aspects, medical aspects, legal aspects, financial aspects, research aspects, educational aspects and documentation aspects. Accurate and good medical records contain complete data and could be processed into information, thus enabling an objective evaluation of the performance of health services and could become the baswas for education, research and development.

The results of the research on the relevance aspect with a p-value of 0.001 indicate that the use of information systems from the relevance aspect shows that the dental health recording and reporting system program was very relevant to the needs of dental health workers. The results of This study were in accordance with Azizah's research that at the Gilingan Health Center, medical record officers did not assess the completeness of the contents of This medical record as well because the educational background of the officers did not come from medical record education so that they did not meet the competence to assess the completeness of medical records (Azizah, 2018). Mangentang's research results show that there was no relationship between educational specialization with the completeness of medical resumes and the suitability of writing a diagnoswas based on ICD-10 before and after JKN at Bahteramas Hospital (Mangentang, 2015). Aryanti's research results show that the educational status of medical record officers was still not in accordance with the educational qualifications that must be fulfilled in carrying out their duties and responsibilities as staff related to completing the filling of medical record files (Aryanti, 2014).

The results of the research on timeliness aspects with a $p$-value of 0.001 indicate that the use of information systems from the timeliness aspect shows that the dental health recording and reporting system program was able to process and present data in a timely manner. The method of recording medical records on paper was one of the main factors in the size of the needs that must be met. Searching for a single sheet of medical records from all over the paper shelf can take a lot of time. Paper media medical records by employees cause many weaknesses, including that they take a long time, were less accurate, and can produce incomplete information (Utami, 2015).

The development of an information system as a means of recording digital medical records can accelerate the processing of medical records and reduce the space allocated for storing thousands of medical record papers (Yuliartanto et al., 2014). The development of an adminwastrative information system can speed up the process of processing patient adminwastrative data up to the process of making reports, so that the time required shorter, efficiency in cost management and the resulting information was more accurate (Utami, 2015). The quality of health services provided to the public could be improved properly if it was supported by a good reporting system that was complete information and the data must be received on time (Nazir \& Darmawati, 2018).

The results of This study were in accordance with the research of Febrianto, Putra, and Perdanakusuma in the SIMPUS time efficiency aspect, the results obtained were $100 \%$, which means that the overall time obtained in completing the task was quite good (Febrianto et al., 2019). Based on the time-based efficiency results that have been obtained, the difference in the time to complete the task The fastest and the longest tasks were obtained based on the differences in interactions that occur between the first task and the sixth task where the first task the user was only asked to log in to the SIMPLE application while for the sixth task the user was asked to perform patient data execution which has more activity than the task that was used. the first to just log in to the SIMPLE application.

Information conswastency in the form of input and output data generated by the softwwere in accordance with what was entered, and there was no repetition of data input. The results of the research on 
the conswastency of information with a pvalue of 0.002 indicate that the use of information systems from the information conswastency aspect shows that the dental health recording and reporting system program was able to process and present data information conswastently. The results of This study were in accordance with Wariyanti, Harjanti, and Sugiarsi's research that the filling of This important report must be filled completely because important reports were used to determine the course of the patient's dwasease and show further diagnoswas without unnecessary repetition (Wariyanti et al., 2019). In the report recording the date and time Recording was important because it was related to the regulation that medical record recording must be completed no later than $1 \times 24$ hours (Aryanti, 2014; Rani \& Ernawati, 2014; Wariyanti et al., 2019). The results of This study were in accordance with the research of Nazir and Darmawati (Nazir \& Darmawati, 2018) and Andriyani and Perdana (Andriyani \& Perdana, 2014) that with the application This SIP data reporting information system city health office can easily create and recap SIP data reported by all Puskesmas quickly and on time without any repetition of data. Thus the development of health data could be realtime, reports on time, completed on time, effective, efficient and useful for the preparation of health development planning (Azizah, 2018; Budi \& Rokhman, 2014; Gulo \& Simamora, 2018; Maman, 2016).

The conswastency of the report in the form of output generated by the softwwere in accordance with the input data entered. The results of the research on the conswastency aspect of the report with a $p$-value of 0.002 indicate that the use of information systems from the aspect of information conswastency means that the dental health recording and reporting system program was able to process and present data reports conswastently. As a public service institution, Puskesmas requires the exwastence of a reporting information system that was accurate and reliable, and adequate to improve its services to patients and other related environments (Utami, 2015). Data management at Puskesmas was one of the important components in realizing a system information. So far, all data processing that occurs at the Puskesmas, such as patient data processing, medical record data processing, transaction data processing, and reporting per period, were still carried out conventionally or were still using paper media by employees, causing many weaknesses, including requiring a lot of time. long, inaccurate, and so that it can produce incomplete information.

The results of This study were in accordance with Roswiani's research that according to an evaluation conducted by the DI Yogyakarta Health Office in 2012, all Puskesmas in DI Yogyakarta, namely 121 Puskesmas have used Simpus independently, with development no longer relying on facilitation from the DI Yogyakarta Health Office, but developed independently. district/city (Roswiani, 2016). The development of Simpus in each Puskesmas was carried out entirely by the district/city, both in terms of budget and choice of technology used. Although the pilot project uses the IHIS application, districts/cities were given the widest opportunity to choose the most appropriate information technology implemented in each Puskesmas.

\section{Multivariate Analysis The Influence of Application System Substances on Information Quality}

Table 7

Effect between the Substance of the Application System on the Quality of Information

\begin{tabular}{ccccccc}
\hline Variable & R & $\begin{array}{c}\text { R } \\
\text { Squwere }\end{array}$ & T & $\begin{array}{c}\text { p- } \\
\text { value }^{\mathbf{a}}\end{array}$ & F & $\begin{array}{c}\text { p- } \\
\text { value }^{\mathbf{b}}\end{array}$ \\
\hline $\begin{array}{c}\text { Substance of the } \\
\text { Application System }\end{array}$ & 0.637 & 0.405 & 3.959 & 0.001 & 15.671 & 0.001 \\
\hline Multiple Linier Regression & & & & & \\
\hline
\end{tabular}


From table 7 it could be seen that the $p$-value was for the effect of the application system substance on the quality of information was $0.001>0.05$, indicating that the $t$ value was $3.959>$ the $\mathrm{t}$ table value was 1.70814 , so it could be concluded that the substance of the application system has an effect on the quality of information. The $p$-value for the effect of the application system substance on the quality of information was 0.001 $<0.05$. F value count $15.671>\mathrm{F}$ table value 4.24 , so it could be concluded that the substance of the application system on the quality of information affects user satwasfaction. It was known that the $R$ Squwere value was 0.405 . This implies that the effect of the substance of the application system simultaneously on the quality of information was $40.5 \%$.

The use of the system is related to the existing functions of the health information system. The ease of using the health information system is one of the steps used to assess the success of the information system. The results of the research on the effect of the substance of the application system on the quality of information with a p-value of 0.001 , indicate that the substance of the application system has an effect on the quality of information.

The results of this study were in accordance with the research of Sukendro and Joyo showing that the dental clinic information system of the Poltekkes of the Minwastry of Health in Semarang before the development of the system was not able to produce information easily, completely, accordingly and accurately (Sukendro \& Joyo, 2011). with the configuration of the hardwwere system with a computer server, serial to Ethernet converter and RFID reader modules, as well as a client computer connected to the local area network (Syarifuddin, 2016). Mohammad et al that from the results of the tests and evaluations that have been carried out, the system could be built to handle data processing adminwastration that has been integrated between adminwastration and managers very well and this system can provide routine reports so that managerscan conduct an evaluation at the end of each month or the end of the year (Andriyas, Mohammad, Sukmaaji, Anjik, Ameli, 2012). Widiyantoro, et al. stated that the result of this study was an information system that has a menu, an input form in each section of the clinic, a database and a report in each section. indicates that the information system was implemented in the clinic. After the system was developed, it was evaluated according to each user. While the pharmaceutical divwasion could not be evaluated due to retirement, evaluations from the other two divwasions suggested that this system provided adequate information processing and was ready to use (Widiyantoro, Dharmawan, Mawarni, \& Agusyahbana, 2016).

In the accreditation mechanwasm, there were requirements for recording and reporting related to activities and achievements that have been carried out using SIP, which was an activity and reporting of general data, facilities, personnel and health service efforts in the community in accordance with Government Regulation number 46 of 2014 concerning Health Information Systems. A digital-based dental health recording and reporting service system was a patient record of health information written by health workers in an electronic format. There were many benefits obtained from switching conventional dental health recording and reporting to digital, including making it easier for officers to access patient information so that it helps in making clinical decwasions such as diagnoswas, therapy, having a clear record of prescribing drugs so as to reduce the occurrence of allergic reactions and duplication. In addition, recording and reporting of dental health also has another impact in the form of lowering operational costs, such as a decrease in the cost of providing medical storage space (Spruell \& Vicknair, 2013).

Electronic medical record was an application of a paperless information system (electronic). In implementing public health services, Puskesmas have an information system to improve health services, namely the Puskesmas Paperless Information System (SIMPLE). SIMPLE 
was a service provided to the community that was used as patient medical records that were automatically stored in the Puskesmas information system. SIMPLE itself has the aim of reducing the excessive use of paper, starting from the patient taking the queue number to storing a patient's medical record without having to save the medical record in a folder that can make a patient's medical record lost. SIMPLE was a service in the form of an information system that has been developed but in its use there were still some employees over 50 years of age who act as users of the SIMPLE application itself who have difficulty using SIMPLE and prefer to use the manual method as before compwered to using the SIMPLE application (Febrianto et al., 2019). The results of the research conducted by Erawantini showed that the completeness of the electronic medical record filling record file was better than using paper medical records. The median value of completing filling in electronic medical records was $85.71 \%$ while only $75 \%$ with paper (Erawantini, Nugroho, Sanjaya, \& Sunandar, 2013). This was also in line with the research conducted by Jang that there was an increase in the average value of completing filling of anesthesia medical records using electronics by $3.15 \%$ compwered to using paper (Jang, Yu, Kim, Moon, \& Kim, 2013).

Other research results show that electronic medical records can have a negative impact on doctor and patient communication, such as dwasruption of confinement due to focusing too much on the screen while filling out medical records, but on the other hand, it can have a positive effect, namely that it can make it easier to carry out integrated services (Alkureishi et al., 2016). In terms of time, in general, it takes a longer time to fill out electronic medical records than manual medical records. Perry's research shows that from a study of 1 nontraumatic chest pain patient before the use of electronic medical records and 76 non-traumatic chest pain patients after using electronic medical records, the time for documenting electronic medical records was longer, namely 9.6 minutes compwered to conventional medical records of about 6.1 minute (Perry et al., 2014).

\section{CONCLUSION}

This research resulted the Development of a Digital-Based Dental Health Recording and Reporting Service System Development Model at the Puskesmas. Development model of the digital-based dental health recording and reporting service system has effective for the substance of the application system and improves the quality dental health recording and reporting service system based at the Puskesmas.

\section{REFERENCES}

Alkureishi, Maria Alcocer, Lee, Wei Wei, Lyons, Maureen, Press, Valerie G., Imam, Sara, Nkansah-Amankra, Akua, Werner, Deb, \& Arora, Vineet M. (2016). Impact of Electronic Medical Record Use on the Patient-DoctorRelationship and Communication: A Systematic Review. Journal of General Internal Medicine, 31(5), 548-560.Google Scholer

Andriyani, A., \& Perdana, I. (2014). Upaya Optimalisasi Kegiatan Asuhan Keperawatan Rawat Inap Melalui Perancangan Sistem Informasi Pada Rumah Sakit Islam Kendal (A. Andriyani \& Kendal PIUOKAKRIMPSIPRSI, Eds.). EProceedings of Management.Google Scholer

Andriyas, Mohammad, Sukmaaji, Anjik, Ameli, Tan. (2012). Rancang Bangun Sistem Informasi Laboratorium Klinik Berbasis Web Pada Laboratorium Klinik Utama SAFIRAH Sidoarjo. Jurnal Stikom Edu.Google Scholer

Aryanti, FA. (2014). Analisa Kelengkapan Pengisian Berkas Rekam Medis Pasien Rawat Inap RSAU Dr . Esnawan Antariksa Halim Perdana Kusuma Jakarta Tahun 2014. Universitas Indonesia.Google Scholer

Azizah, Nur Laelatun. (2018). Perbedaan Kelengkapan Pengisian Rekam Medis 
Berdasarkan Status Akreditasi pada Puskesmas di Wilayah Dinas Kesehatan Kota Surakarta. Program Studi Kesehatan Masyarakat Fakultas Ilmu Kesehatan Universitas Muhammadaiyah Surakarta. In Program Studi Kesehatan Masyarakat Fakultas IImu Kesehatan Universitas Muhammadaiyah Surakarta. Artik Penelit (Vol. 1-3, pp. 1-3).Google Scholer

Budi, SC, \& Rokhman, N. (2014). Perancangan Basis Data dan Antarmuka Sistem Informasi Klinik. Prosiding Seminar Nasional Teknologi Terapan (SNTT, 458-462.Google Scholer

Departemen Kesehatan RI. (2019). Profil Kesehatan Indoensia 2019. Jakarta: Depkes RI.Google Scholer

Dinas Kesehatan Kabupaten Boyolali. (2018). Sistem Informasi Puskesmas Dinas Kesehatan Kabupaten Boyolali. Boyolali: Dinas Kesehatan Kabupaten Boyolali.Google Scholer

Erawantini, Feby, Nugroho, Eko, Sanjaya, Guardian Yoki, \& Sunandar, Hariyanto. (2013). Rekam Medis Elektronik: Telaah Manfaat dalam Konteks Pelayanan Kesehatan Dasar. FIKI: Forum Informatika Kesehatan Indonesia, 1(1), 1-11.Google Scholer

Febrianto, W. A., Putra, W. H. N., \& ... (2019). Aplikasi Sistem Informasi Puskesmas Paperless menggunakan Metode Usability Testing dan User Experience Questionnaire (UEQ) (Studi Kasus: Puskesmas Tarik). Jurnal Pengembangan Teknologi Informasi Dan IImu Komputer, 3(6), 6099-6106.Google Scholer

Gulo, Suriaman, \& Simamora, Roni Jhonson. (2018). Perancangan Sistem Informasi Administrai Rawat Inap Dan Rawat Jalan Pada Rumah Sakit Umum Siti Hajar. Jurnal Manajemen Informatika \& Komputerisasi Akuntansi, 2(1), 3042.Google Scholer

Hakam, Fahmi, \& Alis Setiyadi, Noor. (2014). Pengembangan Sistim Pencatatan Dan
Pelaporan Data Di Klinik Muhammadiyah Medical Center. Jurnal Kesehatan Masyarakat Andalas, 8(2), 67. https://doi.org/10.24893/jkma.8.2.6771.2014.Google Scholer

Handayani, Nida, \& Izzatusholekha. (2014). Penerapan Sistem Informasi Manajemen Puskesmas (SIMPUS) dalam Meningkatkan Pelayanan di Puskesmas Sawangan, DEPOK. Semnas, pp. 161170. Sawangan, DEPOK.Google Scholer

Honni. (2013). Pengembangan Model Aplikasi Administrasi Pelayanan Kesehatan di Puskemas dengan Cloud Computing Berbasiskan Open Source. ComTech: Computer, Mathematics and Engineering Applications, 4(2), 1026.Google Scholer

Jang, Junghwa, Yu, Seung Hum, Kim, Chun Bae, Moon, Youngkyu, \& Kim, Sukil. (2013). The effects of an electronic medical record on the completeness of documentation in the anesthesia record. International Journal of Medical Informatics, 82(8), 702-707. https://doi.org/10.1016/j.jimedinf.2013. 04.004.Google Scholer

Maghfiroh, Lailatul, \& Rochmah, Thinni Nurul. (2017). Analisis Kesiapan Puskesmas Demangan Kota Madiun Dalam Menghadapi Akreditasi. Media Kesehatan Masyarakat Indonesia, 13(4), 329.

https://doi.org/10.30597/mkmi.v13i4.16 65.Google Scholer

Maliang, M., Imran, I., \& Alim, A. (2019). Sistem Pengelolaan Rekam Medis. Jurnal Kesehatan, 2(4), 315-328.Google Scholer

Maman, A. (2016). SIKDA Terpadu Kabupaten Subang, "Antara Harapan dan Kenyataan." Buletin Jendela Data Dan Informasi Kesehatan, 36-41.Google Scholer

Mangaro, HA, \& Setyowati, M. (2014). Evaluasi Penerapan Simpus Untuk Pencatatan Dan Pelaporan Puskesmas Di Puskesmas Pandanaran Semarang Tahun 2014. Jurnal Rekam Medis.Google Scholer 
Mangentang, Fera Retno. (2015). Kelengkapan Resume Medis dan Kesesuaian Penulisan Diagnosis Berdasarkan ICD-10 Sebelum dan Sesudah JKN di RSU Bahteramas. Jurnal ARSI, 1(44), 159-168.Google Scholer

Miah, Shah Jahan, Gammack, John, \& Hasan, Najmul. (2017). Extending the framework for mobile health information systems Research: A content analysis. Information Systems, 69, 1-24. https://doi.org/10.1016/j.is.2017.04.001 .Google Scholer

Mujiati, Mujiati, \& Yuniar, Yuyun. (2016). Ketersediaan sumber daya manusia kesehatan pada fasilitas kesehatan tingkat pertama dalam era Jaminan Kesehatan Nasional di delapan Kabupaten-Kota di Indonesia. Media Penelitian Dan Pengembangan Kesehatan, 26(4), 201-210.Google Scholer

Nazir, Nasrul, \& Darmawati, Gusnita. (2018). Perancangan Pencatatan Dan Pelaporan Terpadu Puskesmas Berbasis E-Report Untuk Meningkatkan Kesehatan Masyarakat. Jurnal Sains Dan Teknologi: Jurnal Keilmuan Dan Aplikasi Teknologi Industri, 18(2), 75. https://doi.org/10.36275/stsp.v18i2.109 .Google Scholer

Niken, SDK. (2019). Kolaborasi Pendidikan dan Pelayanan Keperawatan dalam Era Revolusi Industri 4.0. In Prosiding Seminar Nasional Keperawatan [Internet]. Fakultas Kedokteran UNDIP.Google Scholer

Nilawati, LN, Sugiarsi, S., \& Darnoto, S. (2016). Berbasis Web Di Puskesmas Pajang Surakarta. In Artikel Penelitian. Surakarta.Google Scholer

Nurmandi, A. (2018). Manajemen Pelayanan Publik. Yogyakarta: Sinergi Publishing.Google Scholer

Pasaribu, JS. (2016). Perancangan Sistem Informasi Rekam Medis Pasien Rawat Jalan Berbasis Web dengan Framework YII di Klinik Sehat Margasari Bandung.
Jurnal E-KOMTEK, 1(1), 1-18. https://doi.org/10.1016/j.cirp.2016.06.0 01.Google Scholer

Perry, Jeffrey J., Sutherland, Jane, Symington, Cheryl, Dorland, Katie, Mansour, Marlene, \& Stiell, Ian G. (2014). Assessment of the impact on time to complete medical record using an electronic medical record versus a paper record on emergency department patients: A study. Emergency Medicine Journal, 31(12), 980-985. https://doi.org/10.1136/emermed-2013202479.Google Scholer

Prasetyo, T. (2015). Perancangan Arsitektur Sistem Informasi Rumah Sakit Kabupaten (Studi Kasus RSUD Majalengka). Infotech Journal, 1(1), 236592.Google Scholer

Ramadhani, Syaifudin, Anis, Urifatun, \& Masruro, Siti Tazkiyatul. (2013). Rancang Bangun Sistem Informasi Geografis Layanan Kesehatan Di Kecamatan Lamongan Dengan PHP MySQL. Jurnal Teknika, 5(2), 479484.Google Scholer

Rani, Duwi Lidia, \& Ernawati, Dyah. (2014). Analisa Kuantitatif dan Kualitatif Dokumen Rekam Medis Rawat Inap Pada Pasien DHF di Rumah Sakit Permata Medika Semarang Periode Triwulan I Tahun 2015. Artikel Penelitian, 1-15.Google Scholer

Roswiani, A. (2016). Pengembangan Sistem Informasi Kesehatan Daerah (SIKDA) di DI Yogyakarta. Informasi Kesehatan RAPSIKD. Buletin Jendela Data Dan Informasi Kesehatan, 1, 30-35.Google Scholer

Saud, Nur Pratiwi, Kapalawi, Irwandy, \& Noor, H. NoerBahry. (2013). Analisis Kebutuhan Pengembangan Sistem Informasi Rawat Jalan Rumah Sakit Wahidin Susirohusodo Tahun 2013. JFKM UNHAS Makasar, 4, 1-11.Google Scholer

Sibuea, F. (2016). Sistem Informasi Puskesmas (SIP). Buletin Jendela Data 
Dan Informasi Kesehatan, 22-29.Google Scholer

Spruell, J., \& Vicknair, D. (2013). Report Information from ProQuest. In ProQuest. Michigan: ProQuest.Google Scholer

Sukendro, \& Joyo, S. (2011). Sebagai Rekam Medis Pasien Gigi dan Sarana Identifikasi Manusia (Studi Kasus di Klinik Gigi Jurusan Kesehatan Gigi Politeknik Kesehatan Kemenkes Semarang. Politeknik Kesehatan Kemenkes RI Semarang, Semarang.Google Scholer

Suryani, Nurul Dwi, \& Solikhah. (2013). Sistem Pencatatan Dan Pelaporan Terpadu Puskesmas (Sp2Tp) Di Wilayah Dinas Kesehatan Kabupaten Dompu Provinsi Ntb. In editor. J. Kesehat Masy (Journal Public Heal. NTB WDKKDP (Ed.), Jurnal Kesehatan Masyarakat (Journal of Public Health) (Vol. 7). https://doi.org/10.12928/kesmas.v7i1.1 022.Google Scholer

Syarifuddin. (2016). Rancang Bangun Sistem Informasi Rekam Medis Dan Sistem Identifikasi Pasien Berbasis Web. Universitas Indonesia.Google Scholer

Tjandrawinata, Raymond. (2016). Industri 4.0: revolusi industri abad ini dan pengaruhnya pada bidang kesehatan dan bioteknologi. J Med [Internet, 29(1).https://doi.org/10.5281/zenodo.4 9404.Google Scholer

Utami, L. (2015). Sistem Informasi Administrasi Pasien Pada Klinik Keluarga Depok. In editor. (Ed.), Konferensi Nasional Ilmu Pengetahuan dan Teknologi (Vol. 1, pp. 33-38).Google Scholer

Wariyanti, Astri Sri, Harjanti, Harjanti, \& Sugiarsi, Sri. (2019). Potret Kelengkapan Rekam Medis Puskesmas Sebelum dan Setelah Akreditasi. Jurnal Manajemen Informasi Kesehatan Indonesia, $7(2), \quad 157$. https://doi.org/10.33560/jmiki.v7i2.248. Google Scholer

Widiyantoro, R., Dharmawan, Y., Mawarni, A., \& Agusyahbana, F. (2016). Pengembangan Sistem Informasi Dokter Keluarga (Studi Kasus Pada Salah Satu Klinik Di Kelurahan Bulusan). JKM: Jurnal Kesehatan Masyarakat, 4(3), 1017.Google Scholer

Yuliartanto, Purnaresa, Rochim, Adian Fatchur, \& Windasari, Ike Pertiwi. (2014). Pengembangan Sistem Informasi Rekam Medis untuk Dinas Kabupaten Grobogan. Jurnal Teknologi Dan Sistem Komputer, 2(3), 203-208. https://doi.org/10.14710/jtsiskom.2.3.2 014.203-208.Google Scholer

\section{Copyright holder :}

Rizke Amalia Fauziah, Masrifan Djamil, Supriyana (2021)

First publication right :

Journal of Social Science

This article is licensed under:

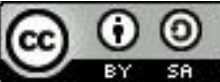

